\title{
PSEUDOTACHYLYTE AND ASSOCIATED FAULT ROCKS AT ALABAMETAAREA, OSUN STATE, SOUTHWESTERN NIGERIA.
}

\author{
O.O. OCAN and A.A. OYAWALE ${ }^{+}$ \\ Department of Geology, Obafemi Awolowo University, Ile-Ife, Nigeria.
}

(Received: June, 2007; Accepted: September, 2007)

\begin{abstract}
This paper reports the occurrence of pseudotachylytes and associated fault rocks along I fewara fault at Alabameta within the Ife-Ilesha Schist Belt, Southwestern Nigeria. The fault separates the schist belt into two lithostratigraphic units: a western unit composed mainly of mafic to ultramafic rocks and metapelites and an castern unit composed of quartzites, quartz schist, metapelites and quartzo-feldspathic (granite) gneisses. These were intruded by granites and pegmatites.

The area was affected by three main episodes of deformation. DI produced recumbent folds probably associated with big nappes and are responsible for the flat lying foliation $\left(S_{1}\right)$ common in this area. D2 produced upright, tight to isoclinal folds responsible for the general notth-south trending foliation $\left(\mathrm{S}_{2}\right)$ and major lithological banding of the belt that define the structural grain of the area. D3 is associated with the major transcurrent faulting (the Ifewara fault), this produced mylonites in the north, near Iwaraja. To the south, the mylonites are locally cut by pseudotachylyte, especially near Alabameta.

The presence of pseudotachylyte is interpreted as a result of frictional melting along the Ifewara Fault, probably associated with a late, high-level movement along the fault.
\end{abstract}

Key Words: Ifewara fault, pseudotachylyte, mylonite and frictional melting.

\section{Introduction}

Alabameta area lies within the Ife Ilesha Schist Belt, which forms part of the Basement Complex of Nigeria. This area has been the subject of a lot of research work because of the famous Ifewara fault and the gold mineralisation associated with the Belt. The area covered by this study lies within latitudes $7^{\circ} 7^{\prime} \mathrm{N}$ to $7^{\circ} 11^{\prime} \mathrm{N}$ and longitudes $4^{\circ} 30^{\prime} \mathrm{E}$ to $4^{\circ} 34^{\prime}$ E.

The geology of the Ife Ilesha Schist Belt as shown on the Geological Survey of Nigeria map reveals the occurrence of the Ifewara fault, separating rocks of the belt into two major lithological facies (Rahaman et al., 1988).

(a) A large sedimentary eastern facies dominated by coarse-grained clastic sediments now represented by quartzite, quartz schist and quartzo-feldspathic gneisses. Fine-grained pelitic rocks constitute a minor unit in the area and are represented by biotite-rich garnet schists.

(b) A volcano-sedimentary western facies composed mainly of mafic-ultramafic rocks referred to as the amphibolite complex (De Swardt, 1953; Hubbard, 1975) associated with minor amount of pelites and psammitic rocks.

Mapping reports of students of the Department of Earth Sciences, Federal University of Technology
Akure, have erroneously indicated the occurrence of 'basaltic' rocks at Alabameta. A detailed examination of the rocks has revealed the existence of ultra mylonites and pseudotachylite associated with the Ifewara Fault near Alabameta Village. It is the aim of this work to describe the occurrence of pseudotachylite, which to the best of our knowledge, has never been reported in this part of the world.

\section{Geological Setting}

The study area is indicated in the published Geological Survey of Nigeria map as being part of the Ife-llesha Schist belt which form part of the crystalline Basement Complex rocks of Nigeria. Nigeria is situated in the pre-drift mobile belt (Burke and dewey 1972) east of the West African and Sao Luis Cratons and north east Congo Craton, affected by the 600 Ma Pan-African Orogeny. The area can be accessed by a major tarred road connecting most of the villages and surrounding towns (Fig. 1). However, accessibility is hampered by thick overburden and rugged topography as most exposures are found along river channels and are highly weathered. A major river (Owena river), trending NNE-SSW direction drains this area. The river has a straight course, 
Fig. 1: Geological map of Alabameta arca

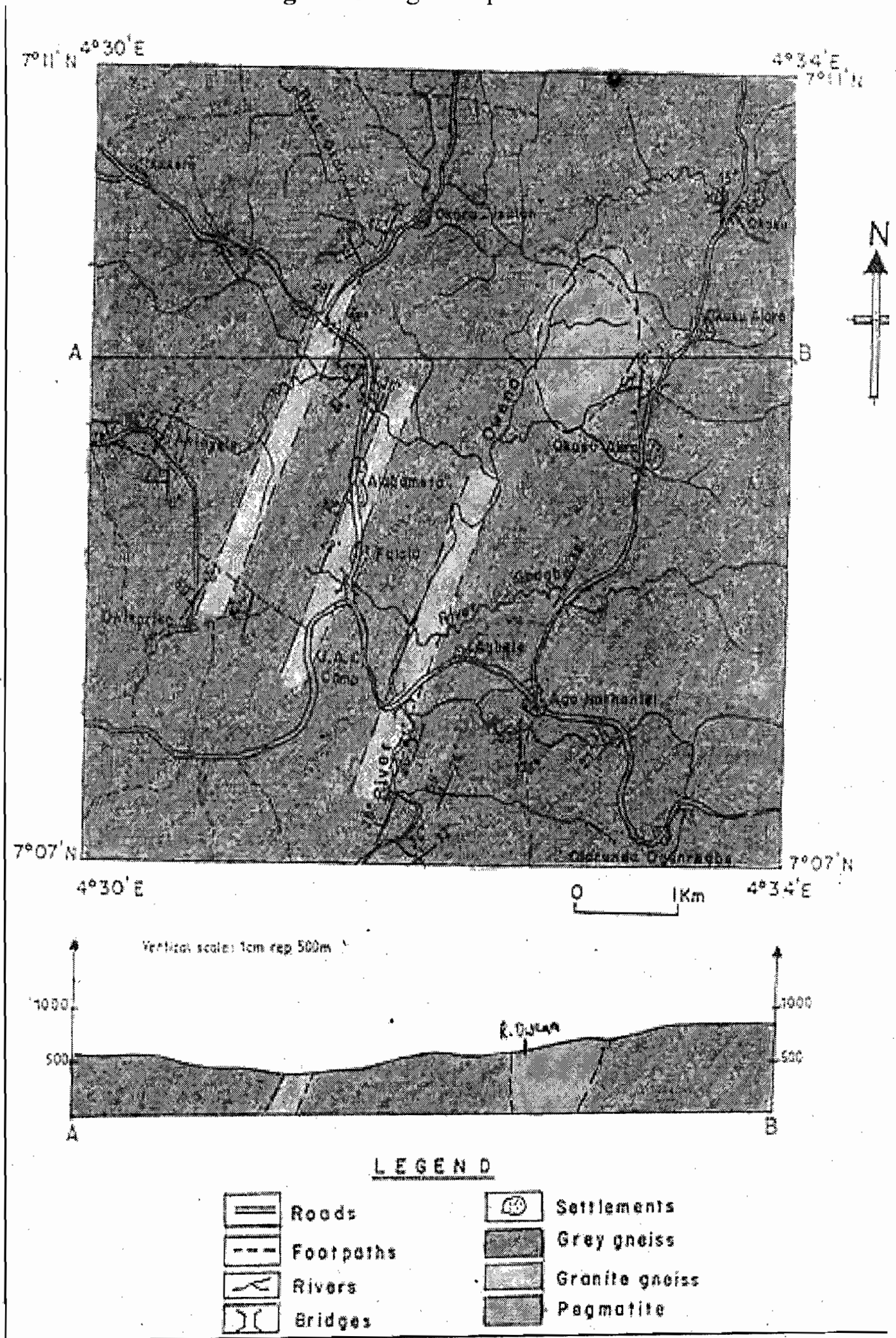


appearing to be structurally controlled with several tributaries and distributaries that also have straight courses and join the main river at approximately right angles giving an essentially trellis type of drainage pattern. However, the first order streams form dendritic drainage pattern. The rocks described in this paper are underlain by the following rock groups (Rahaman, 1976, 1988a):

(i) Migmatite Gneiss - Quartzite Complex,

(ii) Slightly migmatised to non-migmatised metasedimentary and metaigneous rock and

(iii) Members of the Older Granite Suite.

However, the present work suggests that the Alabameta area is underline by migmatitic gneisses.

\section{Materials and Methods}

A detailed geological mapping on the scale of 1:25,000 was carried out in order to determine the geology and structure of the area. Global Positioning Receiver (GPRS) was used to improve location of exposures on the 1:50,000 topographic base map. Twenty-two thin sections of representative rock samples were prepared and studied in detail in the laboratory, using a petrographic microscope; taking note of the types and nature of minerals making up the rocks, their relationship with one another and microstructures present.

\section{Geology/Petrography}

The area covered was found to be underlain mainly by grey gneiss and granite gneiss (Fig. 1). Minor rock types also found within these gneisses are amphibolite, meta-ultramafic rock (amphibole rock), two mica granite, quartzite and pegmatites. Field and petrographic descriptions of the major rock types are discussed below.

\section{Grey Gneiss.}

Grey gneiss in the study area is a dark grey, finemedium-grained, foliated rock. Their foliation is marked by distinct mineralogical banding in which dark coloured bands rich in ferromagnesian minerals alternate with light coloured bands rich in quartz and feldspar. Grey gneiss occurs mainly as a series of isolated low-lying outcrops occupying about eighty percent of the total surface area covered (Fig. 1). It appears to have undergone extensive shearing deformation in several areas, especially at Alabameta area, imparting on the rock a strongly foliated mylonitic fabric.

In some localities, it occurs in close association with amphibolite (e.g. around Okoro Isaiah), and as intercalations (about $3 \mathrm{~cm}$ thick), within granite gneiss. Several quartz and pegmatitic intrusions cut through this rock. Discordant and concordant veins are very common.

Under the microscope, the rock is fine-mediumgrained and the foliation is defined by the alternation of light coloured bands rich in quartz and feldspar with dark coloured bands rich in biotite and amphibole. Mineralogically, the rock is composed of quartz, plagioclase, biotite, amphibole and microline. Muscovite, sphene, zircon, apatite, and opaques occur as accessory minerals.

\section{Quartz:}

Quartz occurs as polygonal grains with triple junctions and occasionally, cuspate grain boundaries are also present. This suggests that the rock has almost completely recovered from the last episode of deformation. The presence of sutured grain boundaries in some thin sections studied is indicative of strain on the rock. Plagioclase is the dominant feldspar present. It occurs in close association with quartz giving a characteristic granoblastic texture in the light coloured bands. Their polysynthetic twin lamellae appear bent, indicative of deformation after crystallisation. Alteration to sercite is common (Fig. 2). Biotite ranges from green to light brown in colour and is strongly plechroic. Their long axes have a preferred alignment parallel to the foliation. The flakes are closely associated with the amphibole and in a few places wrap around the quartzofeldspathic grains (Fig. 3). Cleavage traces of some grains are bent. This is indicative of the occurrence of some kind of deformation. The amphibole present is green in colour and it is probably hornblende. The long axes of the grains have a preferred alignment parallel to the foliation. Most grains are poikiloblastic, towards quartz. Microcline occurs in small amounts, in close association with plagioclase. It shows typical tartan twinning. Muscovite occurs mainly as specks in close association with plagioclase. In a few places, they align themselves with biotite and occur in very small amounts. Sphene is present as an accessory mineral. It contains within it a lot of opaques, giving it a poikiloblastic texture. Apatite and zircon occur as euhedral to subhedral crystals with the quartz grains. It is inferred from the green to light brown colours of biotite that the rock was formed under a low to medium grade of metamorphism. Bent cleavage traces in biotite, bent twin lamella in plagioclase, undulose extinction and sutured grain boundaries in quartz are all indicative of some kind of strain this rock has undergone.

\section{Granite Gneiss:}

In the study area, granite gneiss is a light grey to pink, medium - coarse-grained, strongly foliated rock. The foliation is marked by mineralogical banding where light coloured bands rich in quartz and feldspar alternate with dark coloured bands rich in biotite. In most localities, it occurs as bands of about $8 \mathrm{~cm}$ thick, alternating with bands of grey gneiss. The granite gneiss appears to have undergone extensive shear deformation, along the Channel of Owena River; it has been reduced to mylonites and ultramylonites. 
Fig. 2: Photomicrograph showing plagioclase (P) altering to sericite in grey Gneiss (Cross Polars. Field of view approximately $2.28 \times 3.10 \mathrm{~mm}$ ).

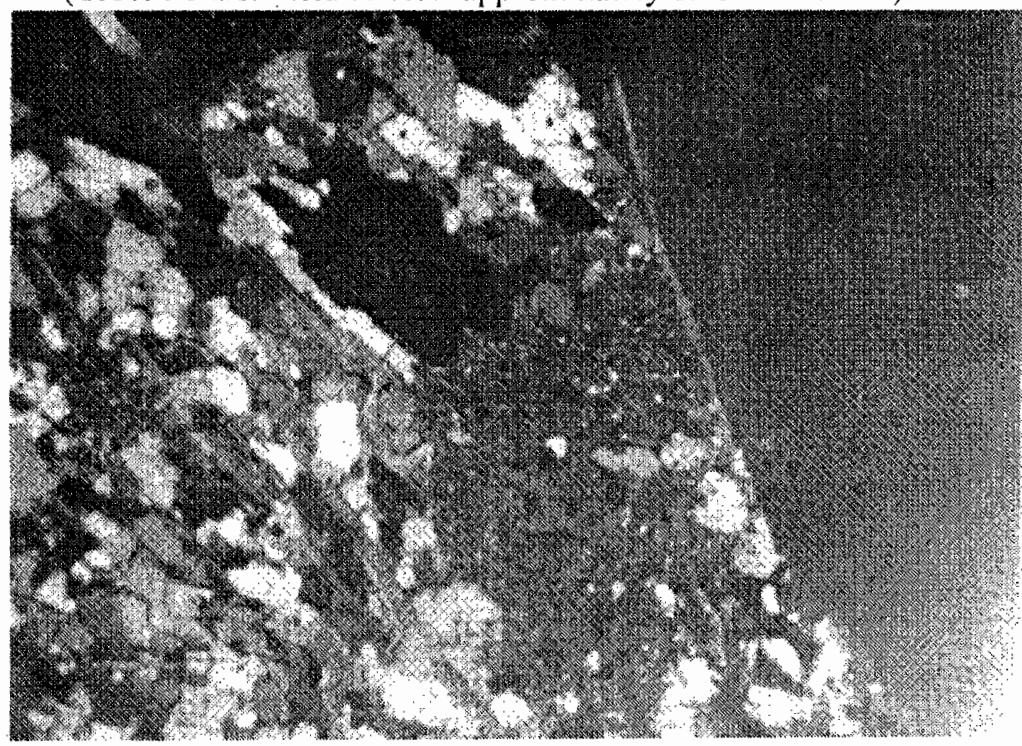

Fig. 3: Photmicrograph showing foliation in grey gneiss marked by preferred orientation of the long axes of the amphibole (A) and biotite (B) grains (Plane polars. Field of view approximately $2.28 \times 3.10 \mathrm{~mm}$ )

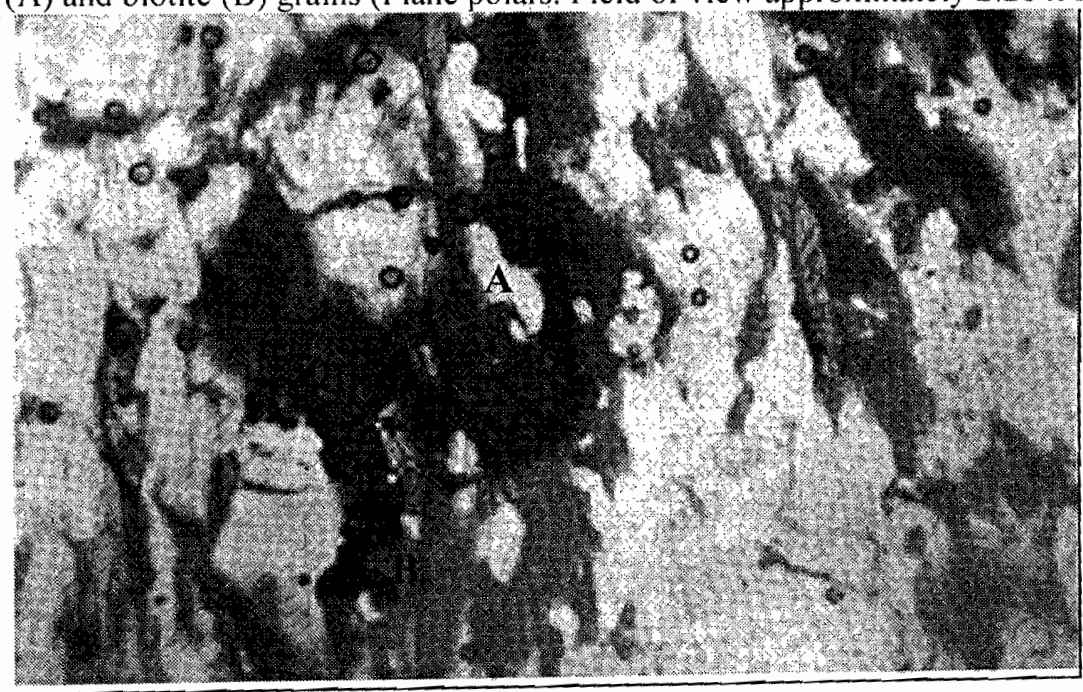

Fig. 4: Photmicrograph showing foliation defined by mineralogical bands of dark green amphiboles (A) alternating with light coloured bands rich in quartz and feldspar $(F)$

(Plane polars. Field of view approximately $2.28 \times 3.10 \mathrm{~mm}$ ).

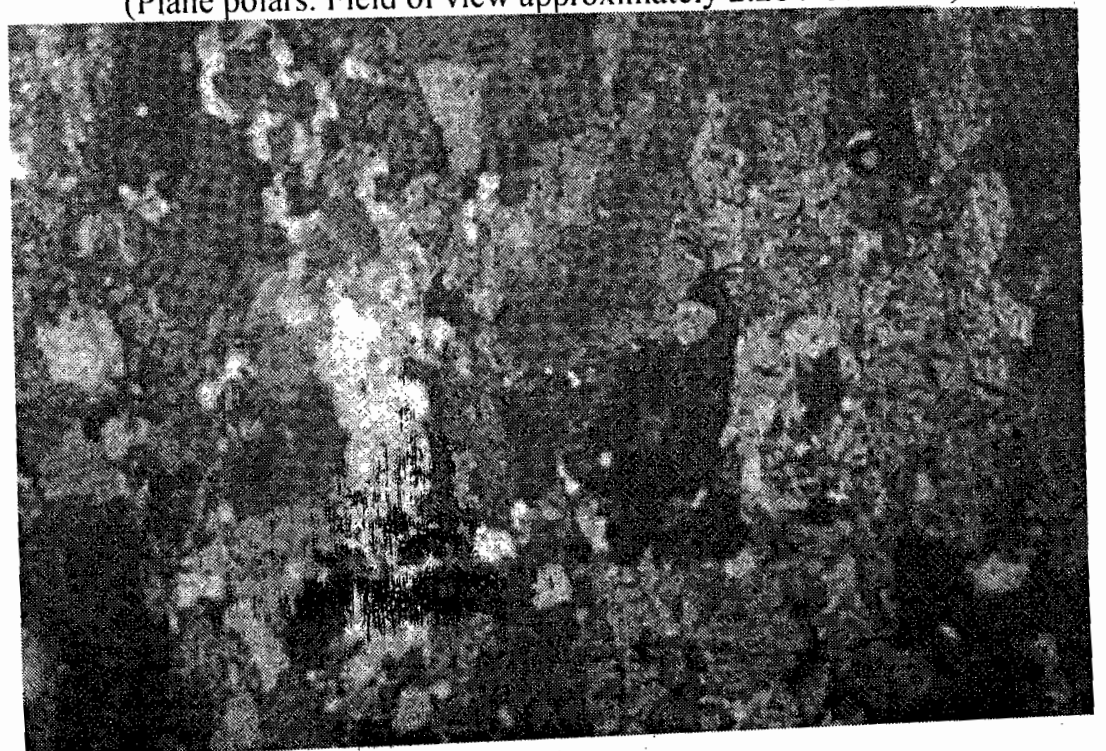


Under the microscope, this rock is medium-coarsegrained and strongly foliated. The foliation is marked by the alternation of light coloured bands rich in quartz and feldspar with dark coloured bands rich in biotite. The long axes of the biotite grains are parallel to the foliation, marked as mineralogical banding. In most of the thin sections studied, the grains show equilibrium texture suggesting that there was a complete recrystallisation after deformation. Mortar texture, in which small polygonal grains of quartz surround larger grains, is common. Mineralogically, the rock is composed of quartz, microline, plagioclase, biotite, and muscovite. Zircon and apatite occur as accessory minerals.

Amphibolite:

Amphibolite is a medium-fine-grained, green to dark green rock. Most of the specimens are massive with a decussate texture. However long a river channel on the way to Okusu Alero, it is foliated. The foliation is marked by a millimetric mineralogical banding, which is defined by the alternation of light coloured quartz and feldspars with dark coloured ferromagnesian minerals. The different types of amphibolites occur as lenses within granite gneiss and grey gneiss on outcrop scale. A few quartzofeldspathic veins (about $0.2 \mathrm{~cm}$ thick) cut across this rock in a random manner. Also associated with them are pegmatites, especially along Falola village. Total area extent of this rock is small. It was not mappable on the scale of the map.

Under the microscope, the rock is foliated in a few sections with its foliation defined by mineralogical bands as dark green amphiboles alternate with light coloured bands rich in quartz and feldspar (Fig. 4). In some other sections studied, the rock is non foliated. Here, the long axes of the amphiboles have random alignment (Fig. 5). Mineralogically, this rock is composed of amphibole, quartz and plagioclase. Sphene occurs as an accessory mineral. From petrographic studies, it appears that not much deformation has taken place on amphibolites in this area. No microstructures were seen. It also appears, from the polygonal grains of quartz present, that there has been full recovery from the last episode of deformation.

Meta-Liltramafic Rock (Amphibole Rock):

Amphibole rock is a coarse-grained, dark green, nonfoliated rock. It occurs as small lensoid bodies within grey gneiss around Akinyele and Onikoriko. They occur as small unmapable units in the area. Under the microscope, the rock is seen to be coarse-grained and non-foliated, in which the amphibole grains show random orientation of their long axes (Fig. 6). Biotite, talc and opaques are also present, but in small amounts.

Petrographic studies reveal an essentially monomineralic rock, made up mainly of amphiboles.
Minerals present show no evidence of deformation. The green to light brown colour of biotite indicates a low to medium grade of metamorphism.

Two - Mica Granite:

The two mica granite is fine-medium-grained, weakly foliated rock. The mineralogical banding that defines the foliation is weakly developed. However, a few samples studied show a strongly developed foliation marked by mineralogical banding in which light coloured bands rich in quartz and feldspar alternate with dark coloured bands rich mica. The rock occurs as minor, unmapable units.

Under the microscope, the rock is seen to be essentially granular. $\Lambda$ few platy minerals however cluster together in some areas to give a discontinuous foliation. Mineralogically, this rock is made up of quartz, biotite, muscovite and microcline. Spheno occurs as an accessory mineral.

Petrographic studies reveal that the two mica granites appear to have undergone certain episodes of deformation, indicated by sutured grain boundarios of quartz, and the mortar texture seen with the microcline.

\section{Quartzite:}

Quartzite occurs as small mappable units in the area. It is a line-grained, light grey to almost white rock. It shows a banding in which lighter coloured bands alternate with darker ones. Quartz and muscovite are identified in hand specimen. Total area extent of this rock is small as it was only seen in one loc... hity. Under the microscope, the rock shows a typical granoblastic texture with interlocking grains of quartz. Mineralogically, it is composed of quartz and minor amounts of muscovite. Petrographic studies reveal that this rock has undergone extensive deformation as indicated by presence of cuspate grain boundaries of quartz.

Pegmatites:

Pegmatites are very coarse-grained, light grey rocks occurring as massive intrusions in the gneiss terra:

They are particularly common around Okusu Alci, and Okusu Alero (Fig. 1). On mylonite of granite gneiss around Agbele, they are seen as veins (about $2-5 \mathrm{~cm}$ thick) cross-cutting the mylonitic foliation within the rock. They occur also with amphibolite in Falola area. Minerals seen prominently on them are large books of muscovite, feldspar and quartz.

Mylonites and Ultramylonites:

The mylonites are light coloured rocks having shallow dips. The ultramylonites are darker, almost black in colour (Fig. 7); they are very brittle with welldeveloped fracture pattern (Fig. 8). Pseudotachylite is seen to occur as small veins enclosing strips of a light coloured leucocratic rock exposed also along this river channel. In some other part of the outcrop, they enclose boudinaged pegmatite (Fig. 9). Under the microscope, mylonite and ultramylonite of grapite 
Fig. 5: Photomicrograph showing the typical appearance of non foliated amphibole $(A)$. Cross polars. Field of view approximately $2.28 \times 3.10 \mathrm{~mm}$.

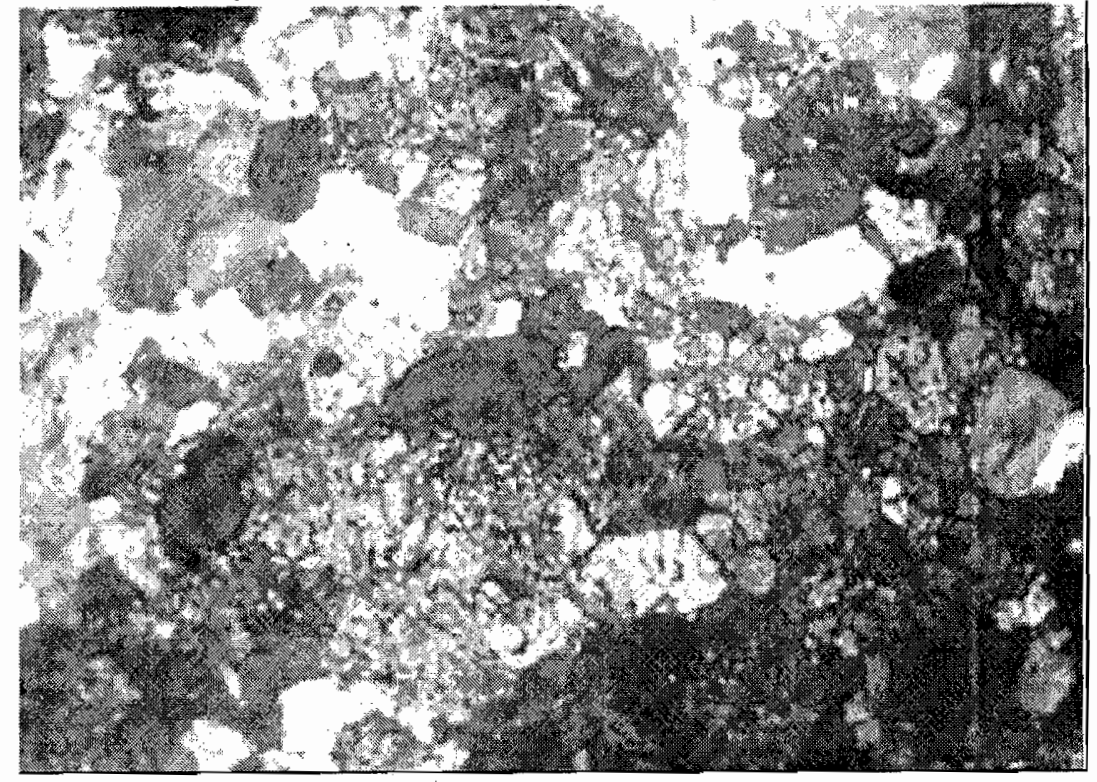

Fig. 6: Photomicrograph showing random orientation of large crystals of amphibole $(A)$ in meta-ultramafic rock (Plane polar. Field of view approximatcly $1.4 \times 2.2 \mathrm{~mm}$ ).

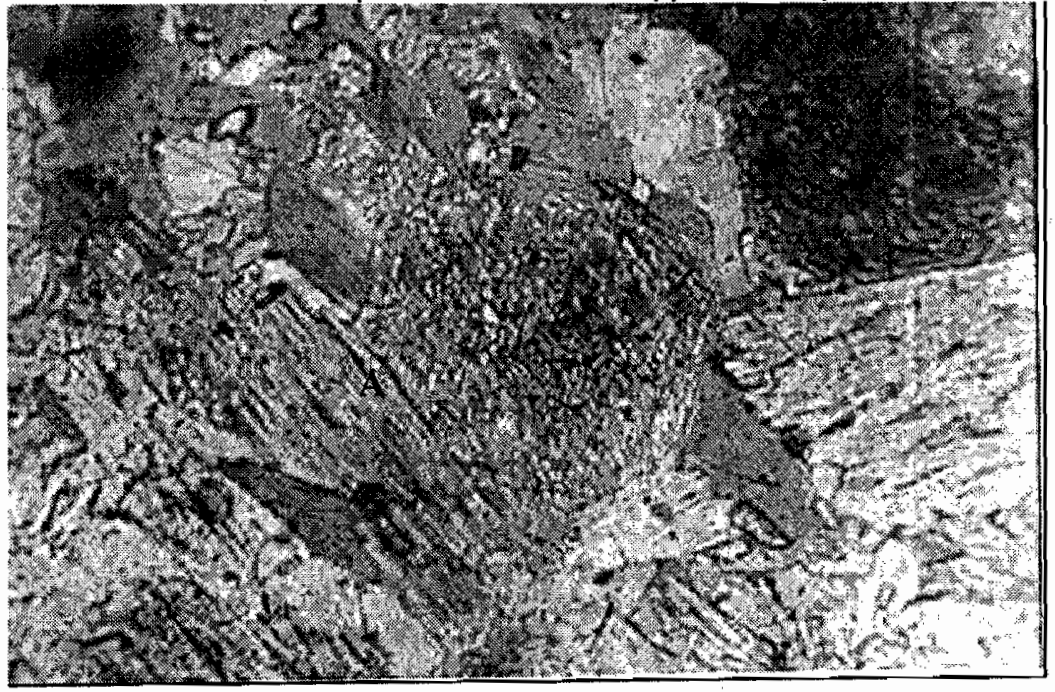

Fig. 7: Photograph of typical appearance of the mylonite of granite gneiss exposed along Owena river channel near Alabameta.

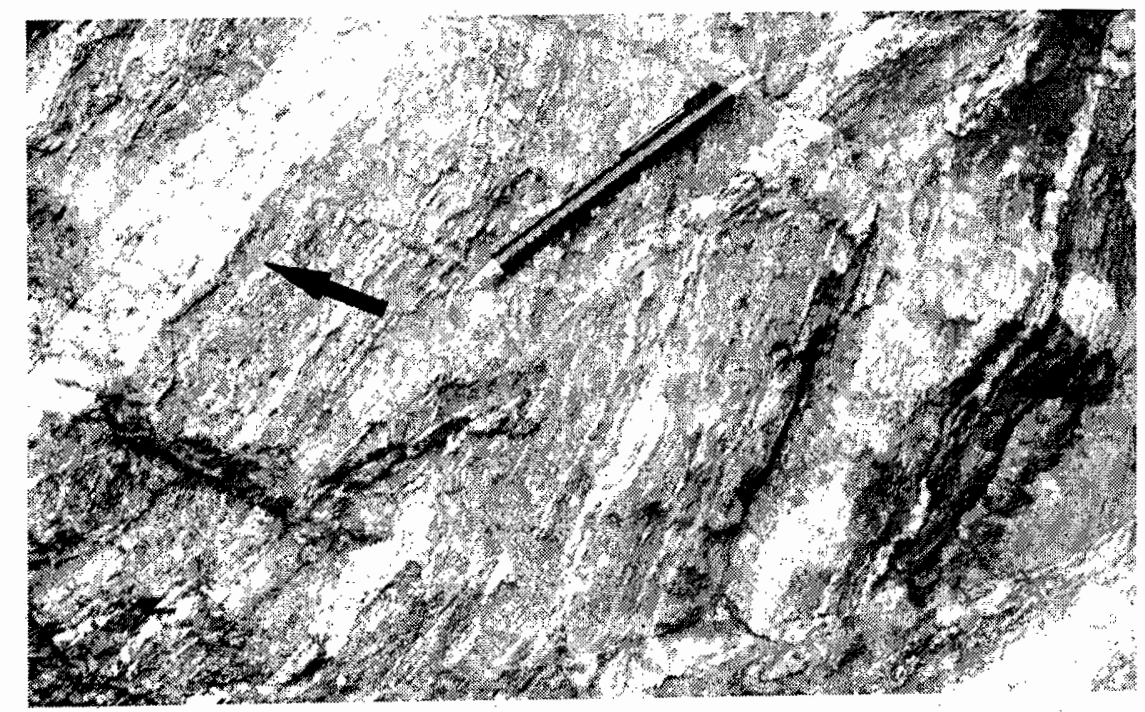


Fig. 8: Photograph showing fractures in ultramylonite ol granite gneiss exposed along Owena river channel by Alabameta.

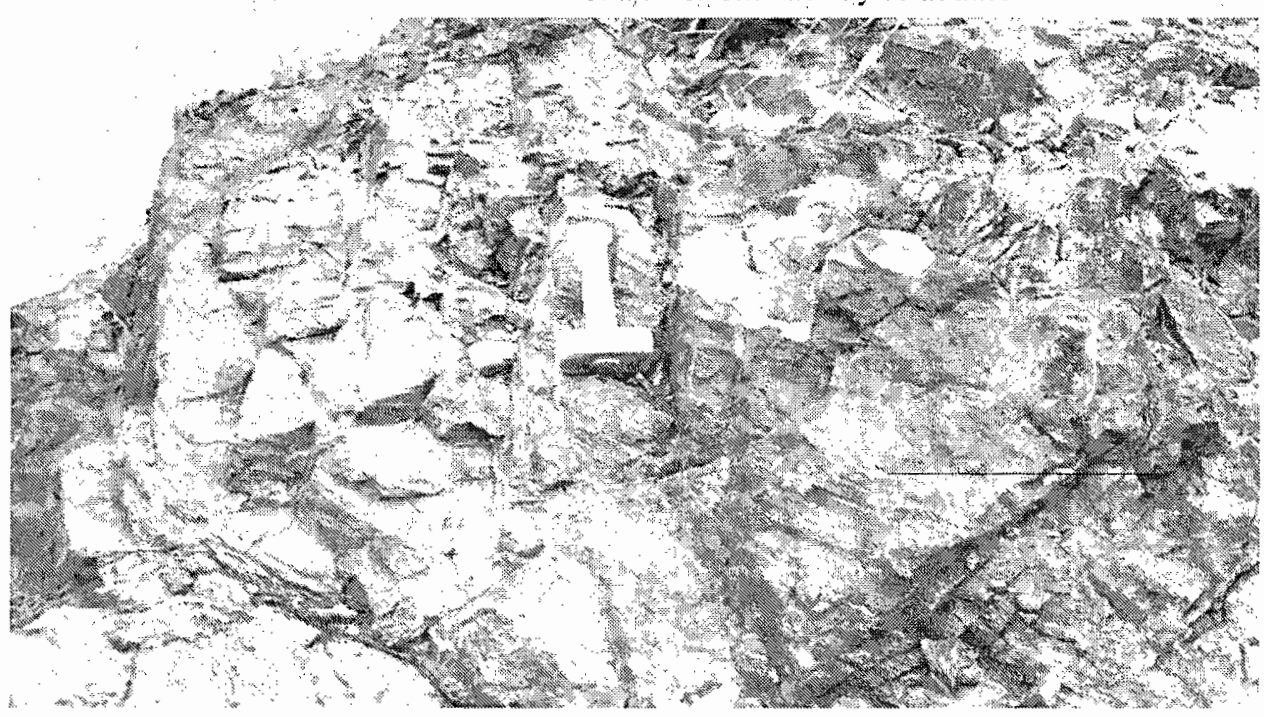

Fig. 9: Photograph of pseudotaclaylyte cnclosing a boudinaged pegmatite exposed along Owena river channel by $\Lambda$ labamacta.

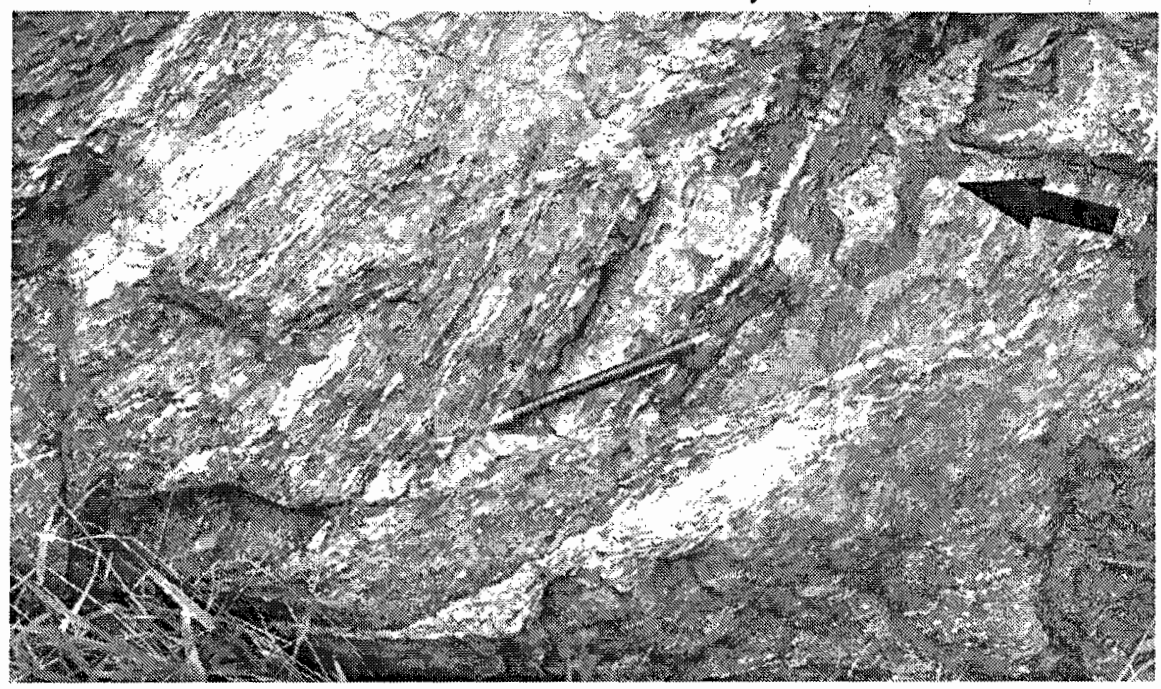

Fig. 10: Photomicrograph showing large porphyroclast of alkali feldspar (AF) within finer mylonitic matrix in ultramylonite of granite gneiss. Note the ribboned quartz $(Q)$ in the matrix

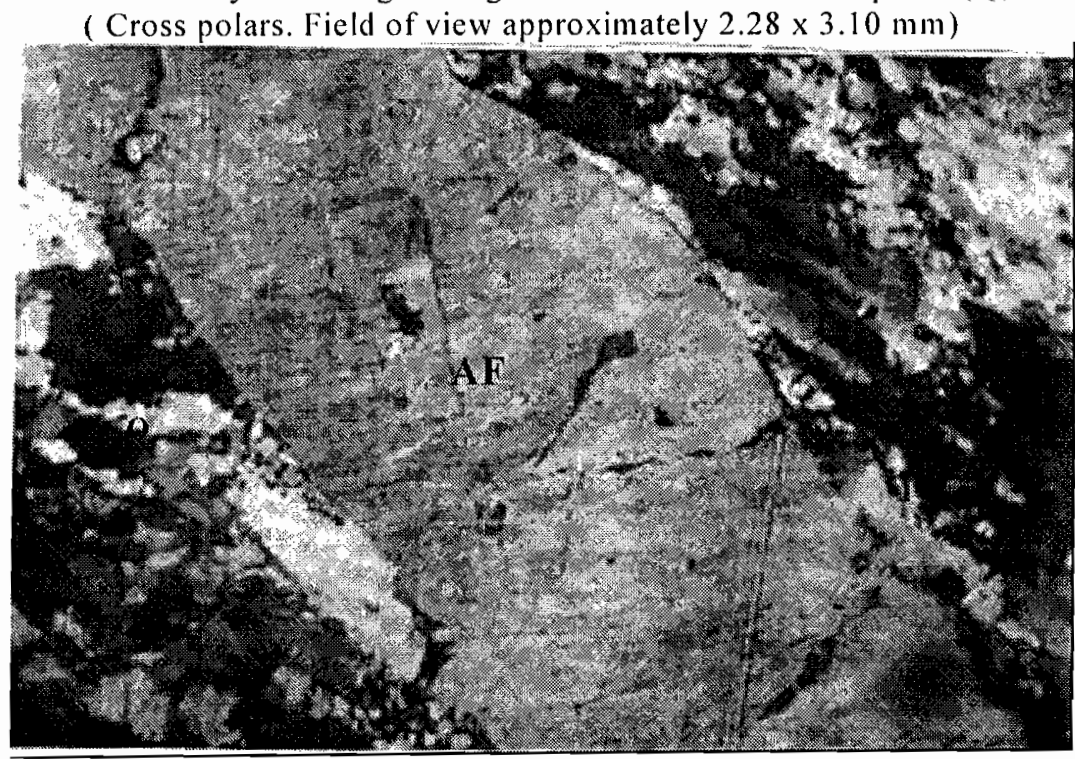


gneiss are fine-grained, dark grey rocks. Large porphyroclasts of feldspars lie within finer mylonitic matrix (Fig. 10 and 11). Most of the mylonitic rocks are not completely crystalline, as small individual mineral grains are embedded within a glassy matrix. Ribboned quartz is typical within the matrix. The matrix is brown in colour and displays a colour banding, which is deformed. Displacements along microfaults are also common (Fig. 12). The crystalline phases present are too small to be identified under the microscope. These rocks, which are partly crystalline, and partly glass, could be identified as pseudotachylyte.

Evidence from petrographic studies of mylonites and ultramylonites of granite gneiss indicate that an extensive shear deformation had taken place. Bent twin famellae in plagioclase, ribbons of quartz observed, cuspate grain boundries and mortar texture of quartz, all point to the existence of some kind of deformation on this rock. However, the polygonal grains of quartz present on a few sections indicate partial recovery after the last episode of deformation.
The green to light brown colouration of biotite is indicative of a low to medium grade of metamorphism. All the units present are deformed. This suggests that the shear deformation was fairly late. The occurrence of rocks that have been identified as pseudotachylite suggest that the shearing took place at shallow crustal levels and /or the rateof deformation was fairly rapid.

\section{Discussion}

Petrographic analysis of the major rock types underlying the study area shows that the rocks appear to have undergone extensive shear deformation. Presence of suture grain boundaries, bent twin lamellae in plagioclase, undulose extinction in quart\% and bent cleavage planes in biotite all point to the fact that these rocks (which are mainly gncisses) have undergone certain episodes of deformation and have only partially recovered from them.

Works of Boesse and Ocan (1988) reveal that about two main episodes of deformation had carlier taken

Fig. 11: Photomicrograph of porphyroclast of alkali feldpars $(A \mathrm{~F})$ within finer mylonitic matrix (Cross polars. Ficld of view approximately $2.28 \times 3.10 \mathrm{~mm}$ ).

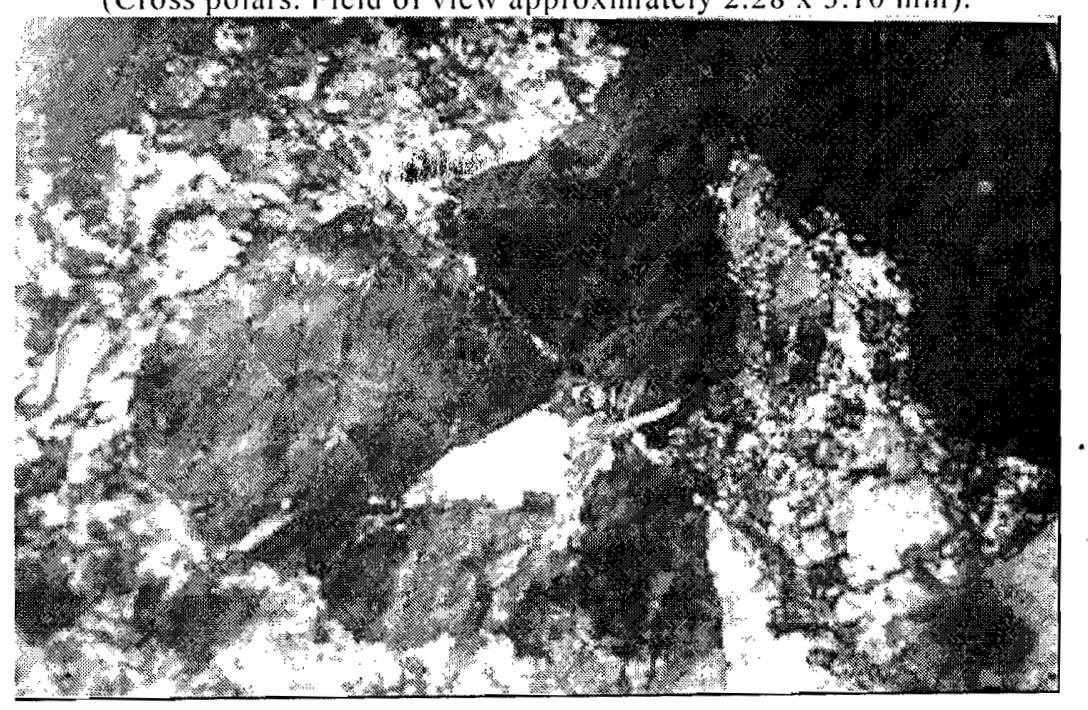

Fig. 12: Photomicrograph showing microscopic faults displacing banding in ultramylonite of granite gnciss

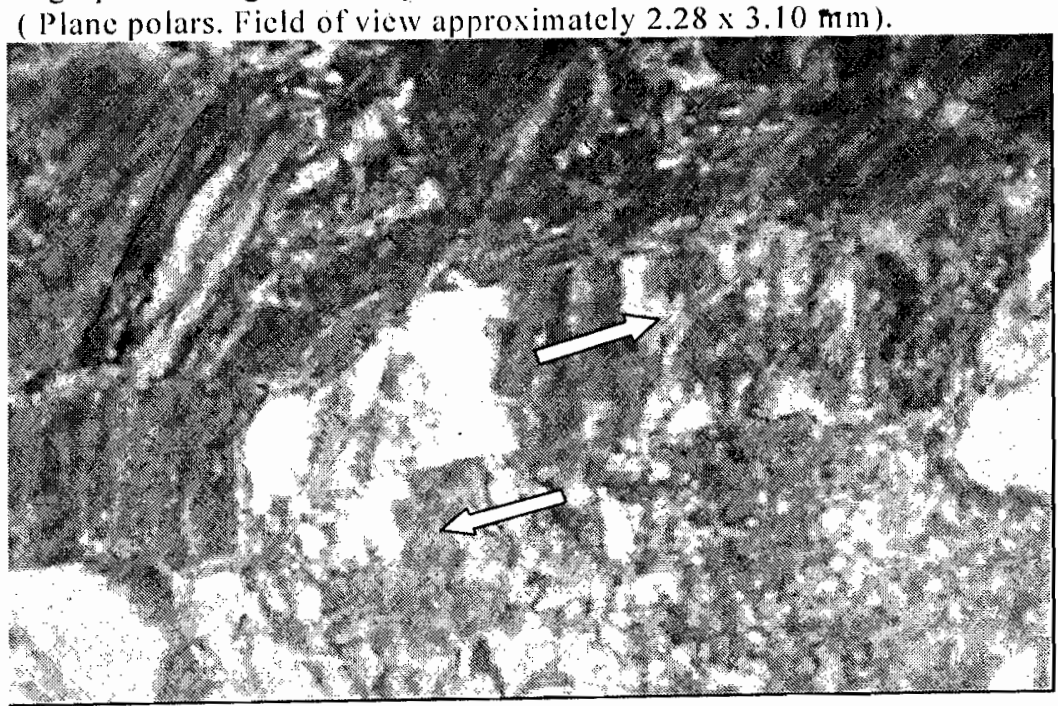


Fig. 13: Regional scale map showing D1 and D2 deformations. (After Boesse and Ocan, 1998).

anth

s.went?

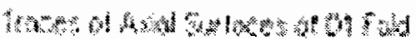

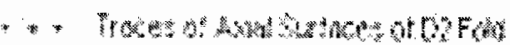

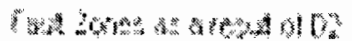

rwethom

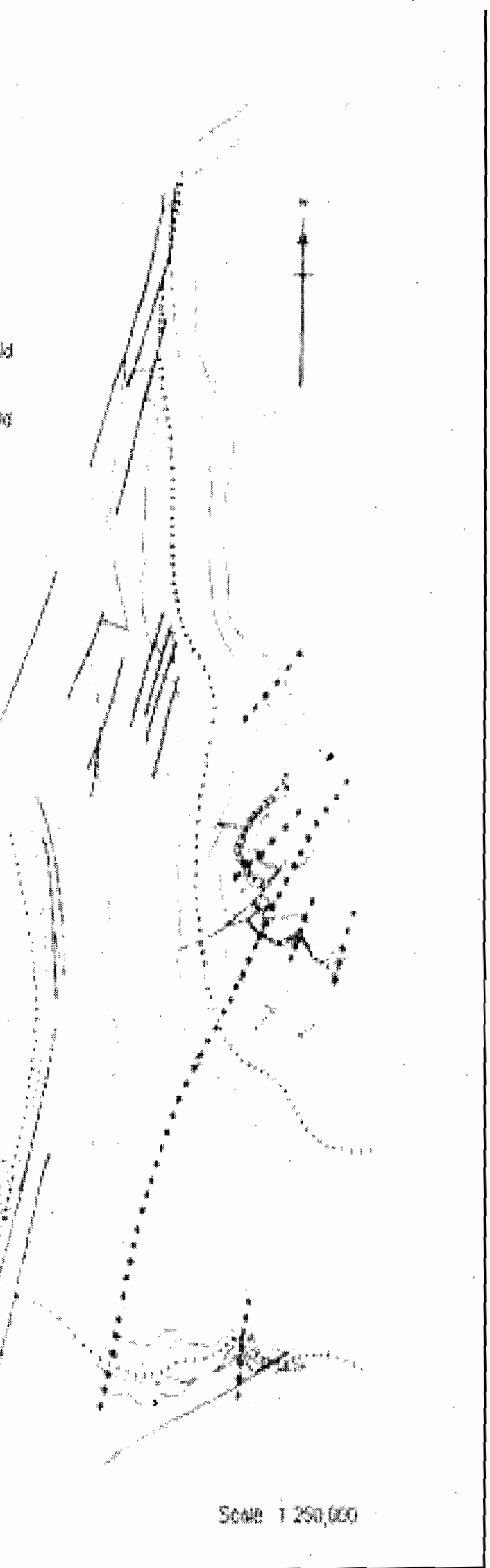


place in the region. The first episode (D1) gave rise to the formation of recumbent folds (F1) Fig. 13. These folds are said to produce axial planar schistosity $\left(\mathrm{S}_{1}\right)$; which is particularly well developed in mica schist and grey gneiss. This first set of folds is related to extensive development of nappes, responsible for the shallow dips near Ilesha. Evidences of this deformation are rare or absent on microscopic scale. The second episode of deformation (D2) produced tight upright isoclinal folds responsible for the general north-south trending foliation $S_{2}$ and major lithological banding of the beit that define the structural grain of the area. The third episode of deformation D3 is known to have produced open metric folds (refolding $\mathrm{Fl}$ ) and big fault zones (creating and reorienting preexisting structures). According to Boesse and Ocan (1988), the open metric folds have steeply dipping axial planes, which may or may not be accompanied by syntectonic foliation $\left(\mathrm{S}_{3}\right)$ such as fracture cleavage. It was shown that isoclinal folds with steeply dipping axial plane schistosity are present in fault zones. This schistosity is replaced by mylonitic foliation (Fig. 14).

The fault zones produced as a result of D3 are related to the formation of mylonitic rocks described in some portion of the study area (along Owena river channel by Alabameta). The mylonite and uitramylonite of granite gneiss seen along this river channel shows slight foliation in form of mineralogical banding by the alternation of light and dark coloured minerals. Pseudotachylyte present, occurs on a small scale as thin veinlets or strips, within the ultramylonite. They have typical glassy appearance showing no form of foliation (Fig. 10). The foliation appears to have been lost from more intense shear deformation. "

Pseudotachylytes are generated by frictional melting, either along deep faults or superficial "super faults" with high velocity and large displacement during a single event (Thompson, 1996). Since the faulted rocks in this area are not of volcanic origin, they are most likely to be a product of frictional melting of the surrounding granite gneiss.

Thompson (1996) explained from geochemical, mineralogical and microtextural results that pseudotachylytes are produced in. high-speed slip zones by frictional comminution and selective melting of host rocks. They occur as local intrusions within the mylonites and ultramylonites of granite gneiss described in this work, as they are believed to form via partial melting and not solely cataclasis. Thompson (1996) further explained that preferential assimilation of hydrous ferromagnesian phases during the formation of pseudotachylytes, led to the production of relatively basic matrices, leaving more resistant quartz and feldspar mineral clasts. This information corresponds to the large clasts of feldspars observed in the petrographic study of ultramylonite of granite gneiss in this present work (Fig. 10 and 11).

\section{Conclusion}

In conclusion, fault rocks described in this thesis are concentrated in a narrow NNE-SSW trending belt: unlike in the northern part of lfe-llesha area where they occur in a broader zone. Exposures of these fault rocks (mylonites and ultran lonites) are seen prominently as vertical to steeply dipping, along Owena river channel near Alabameta. Pseudotachylytes, which has not been described ever before in southwest Nigeria, is described in this thesis as local intrusions within the narrow lfewara fault zone. They are believed to have resulted from partial melting of rocks as a result of further intense cataclasis.

Pseudotachylytes are black, fine-grained to glassy rocks, similar in appearance to tachylytes (glassy basaltic rocks), after which they are named. These ultramylonites of granite gneiss were confused for basaltic rocks. This work however, has been able to show that the supposed basaltic rocks are infact ultramylonites of granite gneiss.

\section{REFERENCES}

Ajayi. T.R., 1981. On the Geochemistry and Origin of the Amphibolites in lle-flesha $\Lambda$ rea. South-West Nigeria. Jour: Min. Geol: 17(2). 179-196.

Ajibade, A.C., 1976). Ptovisional Classilication and Correlation of the Schist Belts of Northwestem Nigeria In C.A. Kogbe (Ed.). Geology of Nigeria lilizabeth Pultishing Co. Lagos. 85-90.

Black, R., Caby, R.. Monssinc Pouchkin. A.. Bayer. R.. Bctrand. J.M., Boullicr. A.M. Fabre. J and I esquer. A.. 1979). Evidenee for late Precambrian plate lectonics in West Africa, Nature, 278. 223-227.

Boessc, J.M. and Ocan O.O.. 1988. Geology and livolution of the fle-llesha Schist Belt. Southwest Nigeria International meeting on Proteroroic Gcology of high grade terrains. Program and lecture series. 26.

Burke, K.C. and Dewcy, J.F., 1972. Orogeny in Arica, In Dessauvagic, T. I. J. and Whiteman. A.J. (lids). Arican Geology - Univ. Ibadan. 1970, 583-608

Caby, R. and Boesse J.M.. 2001. Pan-Aricain Nappe System in South-West Nigeria: The lfe-llesina Schist Beli. Joul: Afri. Earth Sci, 33 (2), 211-225.

Caby, R., Bertrand, I.M. and Black. R.. 1981. Pan-Alican Closure and Continental Collision in the Ioggar-lioras Segment Central Sahara. In $\wedge$. Kroner (lid.) Precambrian Plate Iectonics. Elsevier. Amsterdam. 407-434.

De Swardt, A.M.J., 1953. The (icology of the Country around Jiesha. Builetin. Geol. Surv: Nigeria. Bull 28,54

De Swardt, A.M.I., Van Coppenhagen, J.D.. Ogbukagu. I.K. and Hubbard, F.11.. 1965. The Geological Map of Ifellesha Area. Geol. Su'v: Nigeria 1:250.000 series iwo sheet 60

Elueze. A.A., 1982. Geochemistry of the Ilesha Granite Gneiss in the Basement Complex of South Western Nigeria. In Precambrian Rescarch, 19, 1167-1170.

Elueze, A.A.. 1986. Petrology and Gold Mineralisation of the Amphibolite Belt. Ilesha area. South Western Nigeria. Geologic en Mijinbouw, 65, 189-195. 
Elu世. A A.. 1987. Compositional Characteristics in Relation to the Evolution of Granitic Rock Units in llesha Area. South West Nigeria. Geologie en Mijinbomw; 65. 345-365.

Hubbard. P.H. 1975. Precambrian Crustal Evolution in Western Nigeria. Indications from lwo region: Bull. Geol. Soc. Amer., 86, 548-554.

Kennedy. W. Q., 1964. The Structural Differentiation of Africa in the Pan-African ( \pm 500 M.y) Episode. Research inst. for African Geology (Leeds) 8th Annual Report, $48-49$.

Klemm. D. D.. Schncider. W. and Wagner, B., 1984. Precambrian Metavoleano-Sedimentary Sequence East of tie and Hesha. South West Nigeria-A Nigerian Schist Belt? Jour .1fri. Earth Sci, 2(2), 161-176.

Mc Curry. P.. 1976. The Geology of the Precambrian to lower Paleozoic Rocks of Northern Nigeria. In Kogbe C.A (Ed.). Geology of Nigeria, Elizabethian publishing $\mathrm{Co}$. Lagos. 15-39.

Olade. M.A. and Elucze. A.A. 1979. Petrochemistry of the llesha Amphibolites and Precambrian Crustal Evolution in the Pan- $A$ frican Domain of South West Nigeria. Conit: Precambrian Geol, 8, 303-318.

Oyawoye. M.O.. 1964. The Geology of the Nigeria Basement Complex. Journ. Nigeria Min. Geot. and Met. Soc. 1(2), 87-102.
Rahaman. M.A.O., 1976. Review of the Basement Geology of South Western Nigeria. In Kogbe C.A (Ed.). Geology of Nigeria, Elizabethian publishing Co. Lagos. 41-58

Rahaman. M.A.O., 1988a. Reent Advanees in the Study of the Basement Complex of Nigeria. In Oluyide. P.O.: Mbonu, W.C.; Ogezic. A.E.; Egbuniwe, l.G.; Ajibade. A.C. and Umeji, A.C. (Eds.), Precambrian Geology of Nigeria, 11-4l.

Rahaman, M.A.O., Ajayi, T.R., Oshin, I.O. and Asubiojo. F.O.1., 1988. Trace element geochemistry and geotectonic setting of Ife-llesha Schist Belt. Precam. Geol. Of Nigeria, 1. 241-256.

Rahaman, M.A.O. and Ocan. O.O., 1978). On Relationship in the Precambrian Migmatite Gneiss of Nigeria. Journ. Min. Geol., I5 (1), 23-30

Thompson, L.M., 1996). A Study of Pseudotachylyte Associated with the Sudbury Structure Ontario. Canada. The University of New Brunswick: publ. PhD Thesis.

Turner. D.C. 1983. Upper Proterozoic Schist Belts in the Nigerian Sector of the Pan-African Province ol West Africa. Precamb. Res, 21. 55-79. 